Cochabamba, Bolivia. The heads of state of member nations meet annually.

Members. Argentina, Bolivia, Brazil, Chile, Colombia, Ecuador, Guyana, Paraguay (suspended following the impeachment of President Fernando Lugo in June 2012 but then readmitted in Aug. 2013 following the swearing-in of Horacio Cartes as its new democratically-elected president), Peru, Suriname, Uruguay, Venezuela.

Official languages: Portuguese, Spanish, Dutch and English. Headquarters: Av. Manuel Córdova Galarza, Mitad del Mundo, 170311 Quito, Ecuador.

Website: http://www.unasursg.org

Email: secretaria.general@unasursg.org

Secretary-General: Ernesto Samper Pizano (Colombia).

\section{Asian Development Bank}

A multilateral development finance institution established in 1966 to promote economic and social progress in the Asian and Pacific region, the Bank's strategic objectives are to foster economic growth, reduce poverty, improve the status of women, support human development (including population planning) and protect the environment.

The bank's capital stock is owned by 67 member countries, 48 regional and 19 non-regional. The bank makes loans and equity investments, and provides technical assistance grants for the preparation and execution of development projects and programmes; promotes investment of public and private capital for development purposes; and assists in co-ordinating development policies and plans in its developing member countries (DMCs).

The bank gives special attention to the needs of smaller or less developed countries, giving priority to projects that contribute to the economic growth of the region and promote regional co-operation. Loans from ordinary capital resources on nonconcessional terms account for about $80 \%$ of cumulative lending. Loans from the bank's principal special fund, the Asian Development Fund, are made on highly concessional terms almost exclusively to the poorest borrowing countries.

Regional members. Afghanistan, Armenia, Australia, Azerbaijan, Bangladesh, Bhutan, Brunei, Cambodia, China, Cook Islands, Fiji, Georgia, Hong Kong, India, Indonesia, Japan, Kazakhstan, Kiribati, South Korea, Kyrgyzstan, Laos, Malaysia, Maldives, Marshall Islands, Micronesia, Mongolia, Myanmar, Nauru, Nepal, New Zealand, Pakistan, Palau, Papua New Guinea, Philippines, Samoa, Singapore, Solomon Islands, Sri Lanka, Taiwan, Tajikistan, Thailand, Timor-Leste, Tonga, Turkmenistan, Tuvalu, Uzbekistan, Vanuatu and Vietnam.

Non-regional members. Austria, Belgium, Canada, Denmark, Finland, France, Germany, Ireland, Italy, Luxembourg, Netherlands, Norway, Portugal, Spain, Sweden, Switzerland, Turkey, UK, USA.

Organization. The bank's highest policy-making body is its Board of Governors, which meets annually. Its executive body is the 12-member Board of Directors (each with an alternate), eight from the regional members and four non-regional. The ADB has resident missions in a number of countries. There are also three representative offices: in Tokyo, Frankfurt and Washington, D.C.

Official language: English.

Headquarters: 6 ADB Avenue, Mandaluyong, Metro Manila,

Philippines.

Website: http://www.adb.org

President: Takehiko Nakao (Japan).

\section{Asian Infrastructure Investment Bank (AIIB)}

The Chinese government announced proposals for the establishment of the Asian Infrastructure Investment Bank in Oct. 2013. Articles of agreement, which form the bank's legal basis, were adopted in May 2015 and the institution was formally launched in Dec. that year, with an initial capitalization of US\$100bn.

Aims and Activities. The bank aims to provide financial backing for infrastructure development projects in Asia and to promote regional co-operation to address development challenges. It is expected that the AIIB will work in co-operation with existing international development banks.

Organization. The senior decision-making body is the Board of Governors, comprising one governor from each member state. It is scheduled to meet once a year. A Board of Directors, made up of 12 Governors, oversees the day-to-day running of the organization. There is also a Secretariat, headed by the SecretaryGeneral.

Members. By the end of 2015, 57 nations (37 regional and 20 nonregional) had signed the founding Articles of Agreement and have until the end of 2016 to ratify them in order to secure membership. On 25 Dec. 2015 the AIIB came into force when ratification passed the statutory requirement of at least ten countries holding over $50 \%$ of initial capital stock subscriptions. As of Feb. 2016, 30 countries had become full members.

Official languages: Chinese, English and French.

Headquarters: 9 Financial St., Xicheng District, Beijing, China.

Website: http://www.aiib.org

Email: information@aiib.org

Secretary-General: Jin Liqun (China).

\section{Asia-Pacific Economic Co-operation (APEC)}

Origin and Aims. APEC was established in 1989 to take advantage of the interdependence among Asia-Pacific economies, by facilitating economic growth for all participants and enhancing a sense of community in the region. Begun as an informal dialogue group, APEC is the premier forum for facilitating economic growth, co-operation, trade and investment in the Asia-Pacific region. APEC has a membership of 21 economic jurisdictions that together account for $40 \%$ of the world population, $43 \%$ of world trade and $55 \%$ of world GDP. APEC is working to achieve what are referred to as the 'Bogor Goals' of free and open trade and investment in the Asia-Pacific area.

Members. Australia, Brunei, Canada, Chile, China, Hong Kong, Indonesia, Japan, South Korea, Malaysia, Mexico, New Zealand, Papua New Guinea, Peru, Philippines, Russia, Singapore, Taiwan, Thailand, USA and Vietnam.

Activities. APEC works in three broad areas to meet the Bogor Goals. These three broad work areas, known as APEC's 'Three Pillars', are: Trade and Investment Liberalisation-reducing and eliminating tariff and non-tariff barriers to trade and investment, and opening markets; Business Facilitation-reducing the costs of business transactions, improving access to trade information and co-ordinating policy and business strategies to facilitate growth, and free and open trade; Economic and Technical Co-operationassisting member economies build the necessary capacities to 